\title{
Hinder och möjligheter för forskningsresultats användning - förslag till en analytisk modell
}

\section{CHRISTIAN KULLBERG}

Utgångspunkt för artikeln är resultat från sådan forskning som problematiserar förhållandet mellan forskningen och dess användare, samt teorier om vilka former för att informera och samarbeta somär gynnsamma för forskningsanvändning. På basis av sådan forskning presenteras en analytisk modell som syftar till att systematisera förståelsen av hinder och möligheter $i$ samarbete och samverkan mellan forskningen och användarna. Modellen redogörs för genom att åskådliggöra potentiella kontroverser mellan användare och forskning med anknytning till regionala FoU-verksamheter inriktade på socialt arbete.

\section{"De två sfärerna" och hinder i överföringen av kunskaper}

En av grundstenarna i den gängse teoribildningen om förhållandet mellan forskningen och dess användare inom offentlig förvaltning är föreställningen om två existerande "sfärer", forskningens sfär respektive

Christian Kullberg är filosofie doktor i kommunikation och arbetar som universitetslektor och forskare i socialt arbete vid Örebro universitet. den politiskt - administrativa sfären. Det sociala arbete som socionomer och andra professionella eller ickeprofessionella grupper bedriver inom stat, kommuner och landsting kan hänföras till den politiskt - administrativa sfären, medan till exempel en stor del av den forskning i socialt arbete som bedrivs på universitet och högskolor räknas till forskningens sfär. De båda sfärerna skiljer sig åt på ett antal viktiga punkter (Cheol, 1997: 4; Ginsberg \& Gorostiago, 
2001). Föreställningen om de två sfärerna har i den internationella forskningen fått benämningen "two-communities theory" (se tex. Caplan, 1979). ${ }^{1} \quad$ Bland de skillnader mellan sfärerna som forskningen identifierat märks till exempel den grad av politisk styrning respektive frihet som verksamheten inom dem är underkastad. Ett annat särskiljande drag är frågan om hur forskningens eller kunskapens kvalitet bedöms. De inom forskningsvärlden ofta använda kvalitetskriterierna tillförlitlighet, generaliserbarhet, systematik, teoretisk integration och förklaringsdjup är inte direkt överförbara på och jämförbara med de kvalitetskrav som användarsidan ställer. Inom den senare sfären bedöms istället en

1 Vetenskapen respektive den politiskt administrativa sfären skulle också kunna betraktas som "kunskapsområden", organisatoriska "system" eller "kulturer». Dessa tre begrepp är dock i någon mån för begränsade för den diskussion som förs i artikeln. Detta därför att de har kunskapsfrågor, organisationsfrågor eller idé- och föreställningsmässiga aspekter som huvudfokus. Begreppet "samhälle» har också använts för att illustrera den aktuella distinktionen mellan de båda företeelserna (jfr engelskans "community»). Problematiskt med användandet av begreppet samhälle i detta sammanhang är dock att det ger intrycket av att vetenskap och politik skulle vara två sociala enheter som kan existera helt fristående och oberoende av varandra. Så är emellertid inte verkligheten beskaffad. Även om begreppet "sfär» är relativt vagt är det ändå mest lämpat för artikelns syfte. Begreppet används i framställningen som ett sätt att beteckna ett socialt utrymme eller område av symboler, språkliga aktiviteter, institutioner, verksamheter, praktiker, idéer och föreställningar som har viss autonomi i förhållande till andra sfärer. mer konkret användbarhet som viktigare (Kennedy, 1983; Ashford \& LeCroy, 1991). ${ }^{2}$ Ytterligare ett särskiljande drag är hur man inom de båda sfärerna betraktar kunskapens samhällsrelevans eller "nytta". Även i denna fråga finns ett potentiellt problem i mötet mellan den »inomvetenskapliga» och den "utomvetenskapliga» världen. Relevans ur ett inomvetenskapligt perspektiv bedöms till övervägande del på grundval av interna kriterier. Däremot nagelfars mer sällan sådana externa kriterier ${ }^{3}$ som rör forskningens samhälleliga praktiska användbarhet. Denna skillnad mellan forskningen och dessa avnämare när det gäller relevans märks till exempel inom det sociala kunskapsområdet och kan förklara att det i diskursen om socialt arbete förekommer kritik av forskningen för dess bristande praktiska användbarhet (Tengvald, 1995, 1997a, 1997b; Thyer, 2001). Andra svenska forskare på området instämmer emellertid inte i denna kritik. De menar istället att ett för stort fokus på användbarhet kan innebära att forskningen legitimerar verksamheter snarare än att den kritiskt granskar arbetet för att därmed kunna bidra till faktisk kun-

2 Se tex. Nydén (1992:47ff) för en diskussion kring detta.

3 Nydén (1992:56ff) gör en gruppering av fem typer av kriterier som föreslagits kunna användas som externa kriterier: användarkriterier (möjlighet för användning i produktion och för beslutsfattande), ekonomiska kriterier (ekonomiska effekter av forskningsresultaten), tidskriterier (möjligheten att genomföra FoUarbetet vid en sådan tidpunkt att resultaten blir användbara), konsekvenskriterier (konsekvenser av och risker med FoU-projektet) samt rollkriterier (vilka intressenter berörs, och hur bör forskningen finansieras). 
skapsväxt (se tex. Bergmark, 1993; Morén, 1996; Westlund \& Eriksson, 1995; Eliasson Lappalainen \& Szebehely, 1996).

En förklaring till den diskrepans som finns mellan forskningens och användarnas sfär är de skilda typer av rationalitet som utgör grunden för de båda sfärerna. Forskningen premierar förståelse medan den politiskt - administrativa sfären är inriktad på handling (Riecken, 1969; Lundmark, 1997). Andra menar att forskningen utgår ifrån en "formell« rationalitet, medan yrkeslivet organiseras utifrån en mer "tilllämpad» rationalitet (Nitsch, 1990). Dessa distinktioner knyter an till det faktum att forskningsfrågor oftast är för abstrakta för att de på ett okomplicerat sätt skall kunna ge omedelbara bidrag till den typ av konkret problemlösningar som efterfrågas i yrkeslivet (jfr. Weiss \& Bucuvalas, 1977; Nilsson, \& Sunesson, 1988; Tydén, Josefsson \& Messing, 2000). Socialarbetare har hävdats vara "instrumentella» i sin forskningsanvändning och värdesätta lösningar som är tillräckliga för de tillfälliga och enskild situationer som uppstår i det dagliga arbetet (Ashford \& LeCroy, 1991; Qureshi, 1998:141-143).

Ytterligare andra särskiljande drag mellan forskningen och dess användare är den tidshorisont man arbetar utifrån, samt den kunskapssyn som är grunden i den logik som de båda sfärerna bygger på. Enligt Stål \& Svedberg (1987) har dagsaktuella frågor prioritet inom det praktiska sociala arbetet. Socialarbetare söker därför lösningar från relativt snabbt och enkelt tillgängliga källor, som till exempel från erfarenheter i eget arbete, kollegiala samtal och handledning (DeMartini \& Whitbeck, 1986; Ashford \& LeCroy, 1991). Inom forskningen har man däremot oftast en lång framförhållning. Siktet är inställt på att genom kunskapstillväxt i framtiden erhålla bättre vetande. När det gäller kunskapssynen så har forskningen metoder och regler som skall säkerställa att den »nya kunskapen« har tillräcklig kvalitet. Inom användarnas sfär är kunskaper däremot intressanta $i$ den mån de kan integreras i det praktiska arbetet. Kunskaper som är mer »färdiga» till sin natur, och som efter en relativt översiktlig kontroll kan infogas i arbetet, tillskrivs därför också oftast ett större värde. ${ }^{4}$

\section{Växelspelet mellan forskning och samhälle}

Förklaringar som betonar skillnaderna mellan det sammanhang som vetenskaplig kunskap produceras i och den kontext som kunskapen är tänkt att tillämpas i är vid en första anblick tilltalande. Mycket tyder dock på att den sorts skarpa polarisering mellan forskning och omgivande samhälle, som två - sfärs - hypotesen utgår ifrån, ger en skev bild av förutsättningarna för forskning respektive yrkespraktik (inom den politiskt - administrativa sfären). Så är det till exempel i frågan om forskningens oberoende av sociala faktorer. Studier med vetenskapsteoretisk utgångspunkt har nämligen synliggjort att forskningen inte

4 Liknande slutsatser angående socialarbetares användning av forskning och förhållande till kunskap finner man även i Lagerkrantz (1998). I Lagerkrantz beskrivning framstår socialarbetarnas sätt att förhålla sig till kunskap som mer eklektiskt, intuitivt och strävande efter "helhet" än forskarens. Besluten sker även snabbare och är ofta fattade kollektivt. 
är så autonom som tidigare antagits. Själva arbetet med att dra en gräns mellan vetenskapliga och ickevetenskapliga kunskaper och aktiviteter kan beskrivas som ett socialt konstruktionsarbete som forskare är involverade i för att kunna bevara intellektuell auktoritet och autonomi gentemot politiska intressen (Gieryn, 1983). Studier rörande vetenskapliga kontroverser visar också att forskning istället för att ha en autonom ställning har del i politiska eller samhälleliga kontroverser (Brante, 1984, 1988, 1990).

Annan forskning (se tex. Spector \& Kitsuse, 1977; Holstein \& Miller, 1993) har pekat på att utgångspunkterna för delar av den samhällsvetenskapliga forskningen i grunden är normativa. ${ }^{5}$ Kunskapsområdet sociala problem, vilket utgör en viktig del av socialt arbete, är ett exempel på ett sådant område inom vilket forskningen kan sägas vara sammanvävd med politiken. Kunskapen om det sociala problemet "fattigdom" är till exempel intimt förbundet med de ständiga "förhandlingar" om den sociala verkligheten som pågår mellan olika aktörer på ett diskursivt plan i samhället. En diskussion som "fattigdomsforskningen" är en inflytelserik aktör i (se tex. Halleröd, 1991; Salonen, 1994, 1996).

\section{Institutionella förändringar}

Inte endast på det teoretiska planet har det

5 Med utgångspunkt från detta har det hävdats att det är problematiskt för ett samhälle att i för stor utsträckning lita på forskaren som den »sociala ingenjör» som skall ge lösningar på samhällets sociala problem (se tex. Hirdman, 1995). skett en förändring när det gäller förståelsen av mötet mellan forskning och praktik. Även forskningspolitiskt har det skett en omorientering som kan sägas vara i linje med den ändrade synen (Tydén, 1997a: 13ff). Länge ansågs universitetens och högskolornas främsta uppgifter vara utbildning och forskning. Att informera om forskning tillkom som en uppgift 1977. Numera har universitetens uppgift att informera om forskningen en ny innebörd, som innebär att en dialog mellan praktiker och forskare skall eftersträvas. Vissa forskare menar också att en förändring kan skönjas bland annat på landets högskolor (Brulin, 1998). Även andra institutionella förändringar är i linje med den ändrade synen på länken mellan forskning och praktik (se tex. Tydén, 1995; Socialstyrelsen, 1997a, 1998). En sådan omdaning är de ökade krav på samhällsrelevans som ställs på forskningen (Martin \& Etzkowitz, 2000). Ett exempel på en sådan förändring inom socialt arbete är att så kallade "praktikrelaterade forskningsmiljöer", "regionala kunskapscentra» eller "lokala FoU-enheter", med anknytning till det sociala området, har inrättats. Förhoppningen är att dessa arrangemang skall leda till att forskningen integreras i socialtjänsten (se tex. Westlund, 1997; Ekermo, 2002: 148).

\section{Fokus på dialogen och användarnas produktion av kunskap}

Den förändrade synen på relationen mellan forskning och användare inkluderar även synen på användarnas roll. Av tradition har studier av forskningsanvändning varit 
"sändarinriktad" och fokuserat på hur forskningen på bästa sätt skall kunna föra ut de kunskaper den besitter. Ett typiskt exempel på detta är det "produktfokus" som funnits i studier om forskningsanvändning (se tex. Nilsson \& Sunesson, 1988: 136ff; Paisley, 1993). En sådan forskning som utgår ifrån en enkel överförings- eller input - output metafor har dock börjat ifrågasättas (Chiel, 1997; Rich, 1997). Kritikerna har föreslagits att socialarbetares och andra professioners kunskapsanvändning bäst kan förstås som en process av kunskapsproduktion, i vilken de egna praktiska erfarenheterna spelar en viktig roll (DeMartini \& Whitbeck, 1986; Ashford \& LeCroy, 1991; Saltman \& Greene, 1993; Molander, 1996, 1997). I detta sammanhang har bland annat utvärdering framhållits som en metod som kan användas för att överbrygga gapet mellan teori och praktik (se tex. Cheetham, 1998; Mullen, 1998). Denna nya form av kunskapsproduktion, som vissa framhållit att utvärderingsforskning med anknytning till socialt arbete är en del av (se tex. Soydan, 1998), har hävdats vara mer problemorienterad, interdisciplinär, användaranpassad och ske mer i samspel med olika intressenter. Detta till skillnad från traditionellt disciplinbunden akademisk forskning som är förankrad i en tydlig uppdelning mellan forskningen och den politiskt - administrativa sfären (se Gibbons, Limoges, Nowotny, Schwartzman, Scott \& Trow, 1994).

\section{Betingelser för användning}

Ytterligare en ingrediens i den alternativa bilden av förhållandet mellan forskning och användare är frågan om under vilka betingelser som forskning faktiskt används. Till skillnad från det "produktfokus» som tidigare studier haft pekar det nya perspektivet på att olika aspekter på relationen mellan forskningen och användarna är centrala. Det har visserligen visat sig vara relativt ovanligt att forskningsresultat används på ett direkt sätt inom socialtjänsten (se Nilsson \& Sunesson, 1988; Bergström, 1991; Bergmark \& Lundström, 2000). Forskningen utgör istället en slags "upplysning" och bakgrundskunskap (Weiss \& Bucuvalas, 1977; Albæk 1988:52; Nilsson \& Sunesson, 1988:109). Vissa slutsatser finns dock trots detta om vad som utgör goda betingelser för forskningsanvändning. Viktigt för att nå ett bra resultat tycks till exempel vara att kunskapen är anpassad till användarens behov (jfr. Nilsson \& Sunesson, 1988:109; Naustdalslid, 1990), att den forskning som utförs uppfattas som relevant, samt att användarna har förtroende för forskaren och uppfattar den utförda forskningen som legitim (jfr. Tydén, 1993; Mullen, 1998). En intensiv och varaktig och nära relation mellan forskare och användare har till exempel hävdats kunna bidra till att forskningen får en sådan trovärdighet (jfr. (Nilsson \& Sunesson, 1988; Ginsberg, Mark \& Gorostiago, 2001; Landry, Amara \& Lamiri, 2001:334-336). En annan viktig förutsättning är att det i den administrativa kulturen finns en öppenhet för att distribuera, läsa och diskutera forskningsresultat (Baklien, 1983). Nya kunskaper tycks också ha en större möjlighet att få fotfäste inom offentlig förvaltning om det finns likheter mellan vetenskapens och användarnas sfär. Likheterna kan till exempel bestå i att 
forskarna och praktikerna tillhör samma profession eller institution (Baklien, 1983). Att de har liknande ideologiska och teoretiska utgångspunkter är andra kriterier för överensstämmelse (Mullen, 1998). Vissa menar också att valet av forskningsmetoder har avgörande betydelse för i vilken mån resultaten kommer att användas. I detta sammanhang framhålls bland annat den deltagarorienterade forskningen som speciellt lämpad (se tex. Eikeland \& Finsrud, 1995; Gustavsen \& Sørensen, 1995; Roos, 1996; Mattsson, 2001). ${ }^{6}$

\section{En modell för att beskriva mötet mellan forskningen och dess användare}

Den förda diskussionen har visat att synen på mötet mellan forskningen och dess omgivning har förändrats. Det »sändarin-

6 Olika typer av "deltagarorienterade" metoder, som på ett eller annat sätt knyter an till aktionsforskningen, framhålls som lämpliga för att åstadkomma en "dialog" mellan forskning och praktik (se tex. Eikeland \& Finsrud, 1995; Gustavsen \& Sørensen, 1995; Roos, 1996). Bland de metoder som förhoppningar knyts till märks till exempel användandet av: olika typer av utvecklingskonferenser (se tex. Engelstad, 1993), participatory research (se tex. Holme \& Starrin, 1993), forskningscirklar (se tex. Åhlund, 1990), samt syntespedagogik (Tydén, 1993, 1994 ). Tydén (1995) vill till de nämnda typerna av metoder även föra den typ av fältbaserad forskning som bedrevs på de fältstationer som socialt arbete vid Göteborgs universitet byggde upp i vissa kommuner. För kritiska diskussioner om dessa metoder och de (forsknings)resultat som åstadkoms med hjälp av dessa se till exempel Lysgaard (1982), Eliasson (1987) eller Kalleberg (1993). riktade" och i viss mån "produktfixerade" fokus som tidigare funnits har nyanserats. Istället betonas numera att förståelsen av dialogen och mötet mellan forskare och yrkesverksamma eller praktiker utgör en nyckelfråga (jfr Socialstyrelsen, 1998). Forskning visar också att två - sfärs - hypotesen eller "the two-communities theory" (se tex. Caplan, 1979) behöver modifieras. Skillnaden mellan aktörer från de båda sfärerna är nämligen mindre än vad som tidigare antagits. Sammanfattningsvis betyder detta att forskningsanvändningsfrågan i högre grad än vad som tidigare varit fallet behöver göras begriplig i "relationella» termer, som en fråga om problem och möjligheter med samarbete och samverkan mellan forskning och användare.

För att åskådliggöra vad ett sådant förändrat synsätt innebär presenteras en modellen som ursprungligen har använts för att beskriva de potentiella hinder som finns när det gäller samverkan mellan olika professioner och organisationer (se Danermark \& Kullberg, 1999). Utgångspunkten i modellen är att några dimensioner och domäner är centrala när det gäller att

7 Domänbegreppet har olika innebörder inom olika kunskapsområden, till exempel inom juridiken (i betydelsen det landområde eller territorium som någon har suverän förfoganderätt över) eller datorvetenskap (i betydelsen en grupp av datorer som delar en gemensam adress). I föreliggande arbete används begreppet $i$ enlighet med den betydelse det getts $i$ forskning inom eller med anknytning till den nyinstitutionella inriktningen inom organisationsforskningen (se tex. Johansson, 2002). I den betydelse som begreppet används i artikeln refererar det till att det finns skillnader i auktoritet, målsättningar, organisering och styrning 
förstå orsaker till hinder, kontroverser eller problem kring samverkan. Till väsentliga domäner räknas organisationer och organisatoriska nätverk, yrkesgrupper och professioner samt samhällssektorer och verksamhetsdomäner. Till viktiga dimensioner räknas en diskursiv, en sociologisk och en psykologisk.

\section{Domäner}

De skillnader i auktoritet, målsättningar, organisering och styrning som finns mellan olika delar av offentlig förvaltning är utgångspunkten för föreställningen om att det är meningsfullt att analytiskt skilja ut tre domäner av relationer inom institutioner eller organisationer (jfr. Kouzes, \& Mico, 1979; Sunesson, 1974, 1981, 1989). ${ }^{8}$ Den första av dessa domäner rör förhål-

mellan olika delar av, och mellan olika aktörer inom, offentliga organisationer (till exempel politiker, professionella och administratörer, se Kouzes \& Mico, 1979). Dessa skillnader mellan olika domäner kan i sig ge upphov till konflikter mellan aktörer inom olika domäner, men också mellan olika organisationer i de fall de söker samverka (se Danermark \& Kullberg, 1999).

8 Kouzes \& Mico (1979) nämner faktiskt fyra skilda »domäner« som har betydelse för de mål, och den inriktning, som offentliga serviceorgan har. Dessa är den politiska domänen, den professionella domänen, den administrativa domänen och brukarnas domän. Brukarnas domän innefattar det inflytande som de klienter eller brukare som kommer i kontakt med verksamheten har. Sådana frågor gäller $\mathrm{t}$ ex vilken service de skall erhålla och vilken roll de själva skall ha i arbetet med det aktuella problemet. I artikeln har dock denna senare domän uteslutits. Detta för att förenkla diskussionen. landena inom skilda samhälleliga sektorer eller verksamhetsdomäner. Till denna domän hör sådana uppgifter och aktörer som är knutna till politiska beslut i stat respektive kommun. Den andra domänen rör yrkesgrupper och professioner. Centralt här är de resurser som yrkesgrupper och professioner besitter samt dessa professioners relationer till varandra. Den tredje domänen slutligen, rör organisationer och organisatoriska nätverk. Centralt inom denna är de typer av relationer till andra organisationer i sin omgivning som verksamheter och institutioner har. Inom denna domän är bland annat administrativa frågor centrala.

\section{Dimensioner}

Föreställningen om existensen av analytiska dimensioner som är relevanta när mötet mellan forskningen och dess användare skall studeras tar sin utgångspunkt i forskning utförd av Brante (1983, 1988, 1990). Brante menar att skillnader som uppkommer i de kunskaps- eller vetenskapsbaserade kontroverserna kan studeras utifrån tre analytiska dimensioner, en teoretisk eller om man så vill diskursiv, en sociologisk och en psykologisk. Den diskursiva dimensionen innefattar kulturellt, kognitiva komponenter i form av tankesätt eller institutionaliserade legitimeringssätt. Den sociologiska innefattar vissa specifika institutionaliserade beteendemönster. Den psykologiska dimensionen, slutligen, innefattar sådana komponenter som kan hänföras till enskilda individers värderingar eller sätt att uppträda, varsebli eller tänka. 


\section{Modell}

De två nämnda aspekterna på samverkan (domäner och dimensioner) som redogjorts för ovan kan sammanfogas till en modell (se figur 1).

Modellen skall förstås på följande sätt när den tillämpas på mötet mellan forskning och forskningsanvändare. Om man till exempel betraktar den diskursiva dimensionen (de teorier eller tanke- och legitimeringssätt som existerar), den sociologiska dimensionen (de institutionaliserade beteendemönstren) eller den psykologiska dimensionen (enskilda individers värderingar och kognition) så kan skillnader mellan forskning och användare specificeras med utgångspunkt i de tre domänerna som rör samhällssektorer, professioner och organisationer. Relationen mellan forskare och användare är med andra ord beroende av de förhållanden som kan identifieras i modellens nio fält.

I en avslutande diskussion som struktureras utifrån de tre presenterade domänerna skall figurens användbarhet för förståelsen av mötet mellan forskningen och dess användare prövas. För att tydliggöra vilka krafter (aktörer och intressen) som opererar i forskningsanvändningsfrågan på det social området kommer diskussionen att kopplas till den skärningspunkt mellan de båda sfärerna som regionala FoU-enheter med anknytning till socialt arbete utgör. Detta görs genom att redogöra för några potentiella kontroverser som finns mellan forskningen och dess användarna i FoUfrågan. Av utrymmesskäl är diskussionen relativt skissartad och har snarare karaktären av en introduktion än en fullstän-

\section{Figur 1.}

En analysram för samverkansprojekt (Hämtad från Danermark \& Kullberg, 1999: 68).

\begin{tabular}{|c|c|c|c|}
\hline \multirow[t]{2}{*}{ Domäner } & \multicolumn{2}{|c|}{ Dimensioner } & \multirow[b]{2}{*}{$\begin{array}{l}\text { Psykologisk } \\
\text { (Enskilda indi- } \\
\text { viders värderingar } \\
\text { och tänkande) }\end{array}$} \\
\hline & $\begin{array}{l}\text { Diskursiv } \\
\text { (Tanke- och legi- } \\
\text { timeringssätt) }\end{array}$ & $\begin{array}{l}\text { Sociologisk } \\
\text { (Institutionaliserade } \\
\text { beteendemönster) }\end{array}$ & \\
\hline $\begin{array}{l}\text { Samhällssektorer/ } \\
\text { verksamhetsdomäner }\end{array}$ & $\begin{array}{l}\text { Politiska mål, } \\
\text { lagar etc som } \\
\text { reglerar verk- } \\
\text { samheter }\end{array}$ & $\begin{array}{l}\text { Organisation specifik } \\
\text { för en speciell samhälls- } \\
\text { sektor. ("socialvårds- } \\
\text { kultur" etc.) }\end{array}$ & $\begin{array}{l}\text { Världsbild, sam- } \\
\text { hälls- och män- } \\
\text { niskosyn }\end{array}$ \\
\hline $\begin{array}{l}\text { Yrkesgrupper och } \\
\text { professioner }\end{array}$ & $\begin{array}{l}\text { Kunskaper och } \\
\text { förklarings- } \\
\text { modeller (teorier) }\end{array}$ & $\begin{array}{l}\text { Yrkes/professions- } \\
\text { kultur, allianser } \\
\text { och nätverk }\end{array}$ & $\begin{array}{l}\text { Sätt att "rama in", } \\
\text { se på och förstå } \\
\text { ett specifikt } \\
\text { problem }\end{array}$ \\
\hline $\begin{array}{l}\text { Organisationer och } \\
\text { organisatoriska } \\
\text { nättverk }\end{array}$ & $\begin{array}{l}\text { Ideologier och teorier } \\
\text { och verksamhetens } \\
\text { funktion och innehåll }\end{array}$ & $\begin{array}{l}\text { Institutionaliserad } \\
\text { arbetsordning, rutiner } \\
\text { och andra arrangemang } \\
\text { som legitimerar och } \\
\text { sätter gränser för en } \\
\text { verksamhets anspråk } \\
\text { och åtaganden }\end{array}$ & $\begin{array}{l}\text { Individuellt } \\
\text { internaliserade } \\
\text { beteendemönster } \\
\text { och handlingar }\end{array}$ \\
\hline
\end{tabular}


dig analys av modellens möjligheter och begränsningar.

\section{Samhällssektorer och verksamhetsdomäner}

Med utgångspunkt i domänen samhällssektorer och verksamhetsdomäner är det relevant att uppmärksamma hur mötet mellan forskningen och dess användare i ett FoU-perspektiv behandlas på det politiska området. Frågan om mötet inom den aktuella domänen kan betraktas ur en diskursiv dimension och rör då de mål som från politiskt håll sätts för FoU-verksamhet. I den sociologiska dimensionen är utgångspunkten i den aktuella domänen de skilda kulturer och sätt att organisera verksamheterna som finns mellan stat och kommun, men också mellan olika statliga sektorer med betydelse för FoU-frågan. Inom den psykologiska dimensionen, slutligen, kan FoU-frågan studeras med utgångspunkt i enskilda aktörernas värderingar och tankar om det aktuella fenomenet.

Även om det naturligtvis är möjligt att studera enskilda individers värderingar inom samhällssektorer och verksamhetsdomäner, så är möjligheten begränsad att göra denna typ av analys inom ramen för föreliggande artikel. För ett sådant arbete skulle det krävas tillgång till intervjustudier som gjorts med aktörer på strategiska positioner inom den aktuella domänen. Sådana studier har dock varit svåra att finna. Diskussionen om förhållandena inom den aktuella domänen kommer därför i huvudsak att röra den diskursiva respektive den sociologiska dimensionen. Utifrån dessa båda perspektiv är det relevant att uppmärksamma att det är två skilda inriktningar inom välfärdspolitiken, den socialpolitiska och den utbildnings- och forskningspolitiska, som har inflytande över FoU-frågan på statlig nivå. Utöver detta är det även två skilda politiska system som möts i FoU-verksamhet inriktad mot sociala frågor, den kommunala respektive den statliga sektorn.

Studerar man FoU-frågan utifrån ett forskningspolitiskt perspektiv så framkommer en dubbelhet eller ambivalens beträffande forskningens ansvar för regionalt FoU-arbete, och därmed även forskningens stöd till praktiskt socialt arbete (se Ekermo, 2002: 217-223). I forskningspolitiken framställs forskningen å ena sidan som en viktig förändringskraft i samhället. Forskningen skall vara samhällsrelevant, och antas kunna främja förändring, förnyelse och tillväxt. Den så kallade »tredje uppgiften", att samverka med det omgivande samhället, har också sedan 1970-talet tillskrivits en ökad betydelse. $\AA$ andra sidan betonas även forskningens frihet, och kunskapsproduktionens egenvärde. Det anses att en autonomi skall upprätthållas gentemot kortsiktiga och för snäva intressen från politik och näringsliv. Forskningen anses också vara bäst lämpad att själv bedöma den vetenskapliga kvalitet. Till den distansering från det konkreta FoU-arbetet ute i landets kommuner som detta implicerar kan också läggas att det i den forskningspolitiska diskussionen framförs argument om att universitet och högskolor inte primärt är inrättade för att utföra uppdragsforskning (Utbildningsdepartementet, 1999).

Det är också intressant att studera hur relationen mellan forskningen och det sociala arbetet behandlas av de krafter eller 
aktörer inom den aktuella domänen som agerar på det socialpolitiska området. Politiska initiativ på detta område tyder på att frågan om att knyta det sociala arbetet närmare ett "vetenskapligt förhållningssätt» har hög prioritet. Ett exempel är regeringens initiativ till det treåriga utvecklingsprogrammet "Nationellt stöd för kunskapsutveckling inom socialtjänsten" (se Socialstyrelsen, 2000). Studerar man de direktiv som regeringen ger för programmets genomförande finner man att där betonas forskningens betydelse för det praktiska sociala arbetet. FoU-enheterna beskrivs emellertid inte som någon egentlig resurs i detta "vetenskapliggörande» av det praktiska sociala arbetet, men nämns ändå i skrivningen eftersom det i uppdraget ingår att ge:

"förslag till struktur och finansiering av verksamhetsrelaterade systematisk och jämförande empirisk forskning samt förslag till nya samarbets- och organisationsformer för den fortsatta utvecklingen av lokala och regionala FoU-verksamheter" (Socialstyrelsen, 2000:122, min kursivering).

Vad denna skrivning rent konkret får för konsekvenser för FoU-tanken är oklart. Intrycket är dock att aktörer inom staten även fortsättningsvis avser att ha inflytande över utvecklingen av de lokala FoU-enheterna. Skrivningen kan också tolkas som att närmandet mellan forskningen och brukarna betraktas ur ett "top-down" perspektiv som innebär att kunskaper och metoder, snarare än att de skall utvecklas i en dialog, så att säga skall "föras ned» eller "föras ut" till användarna (se Socialstyrelsen, 2000, bilaga 1).

Ett kontrasterande perspektiv på FoU- verksamheterna får man om man studerar förarbetena till det socialstyrelsestödda programmet "Forskning och praktik» (Socialstyrelsen, 1997b). Med bland annat ekonomiska medel för igångsättande av FoU-enheter har Socialstyrelsen genom detta program gett stöd till uppbyggnaden av FoU-enheter i kommunerna. Inom programmet betonas utvecklandet av kunskaper om "kunskap i handling", det vill säga lärdom om sådana teorier och metoder som socialarbetare använder i sitt arbete. Den deltagarorienterade, participatoriska forskningen ses i detta sammanhang som användbar (Socialstyrelsen, 1997b). Till skillnad från det perspektiv som kan utläsas av direktiven till »Nationellt stöd för kunskapsutveckling inom socialtjänsten« verkar alltså programmet »Forskning och praktik» snarare grundas på en "bottom-up» - modell.

Som framgår tycks det finnas olika motiv och drivkrafter från statligt håll när det gäller FoU-enheternas framväxt och fortlevnad. $\AA$ ena sidan är den statliga hållningen att uppdragsforskningen inte är en uppgift för universitet och högskolor. $\AA$ andra sidan finns förhållanden som tyder på att den traditionella akademiska forskningen skall ges initiativet när det gäller metodutveckling och utvärdering av socialt arbete ute i kommunerna. ${ }^{9}$ Till detta kan

9 Tillskapandet av Centrum för utvärdering av socialt arbete (CUS) 1993 kan även det ses som ett initiativ i samma riktning. CUS är en enhet inom Socialstyrelsen som bland annat arbetar med att utveckla instrument och metoder för socialt arbete, att främja utvärdering av det sociala arbetets effekter samt att göra kunskapssammanställningar på det sociala områ$\operatorname{det}$ (Socialstyrelsen, 2002b). 
fogas att det dessutom finns krafter som arbetar för att stärka en "användarstyrd" utveckling vid FoU-enheterna (jfr. Socialstyrelsen, 1997b).

Betraktas forskningsanvändningsfrågan utifrån ett kommunalpolitiskt perspektiv kan det konstateras att kommunerna av tradition hävdat sin självbestämmanderätt gentemot staten. En "styrning» eller inblandning i lokala FoU-verksamheter från statligt håll är därför inte oomtvistad. En stark aktör i detta sammanhang är Svenska kommunförbundet som företräder kommunernas intressen. Utifrån ett kommunalt perspektiv kan tillskapandet av FoU-enheterna både sägas ha ett symbolvärde och ett värde som ett konkret verktyg. FoU-verksamheterna kan från ett kommunalpolitiskt perspektiv ses som ett sätt att påvisa att man är framåtsträvande (se Ekermo, 2002: 184). FoU-arbetet i kommunerna är dock $i$ viss mån även underkastat den kommunala hierarkin och de är därmed en del av det politiska maktutövandet (se Ekermo, 2002: 164-167). Ett viktig inslag av den svenska diskursen kring FoU-enheter på kommunal nivå har också varit föreställningen om att dessa enheter skall kunna fungera verksamhetsutvecklande eller tjänsteutvecklande i en relativt snäv bemärkelse. Detta skulle kunna tolkas som att dessa miljöer skall användas som redskap eller utförare för det politiska uppdraget snarare än som fristående forsknings- och utvecklingsenheter (se tex. Westlund, 1997). Sammantaget innebär det sagda att FoU-organisationerna som fenomen redan är, och fortsättningsvis också riskerar bli, föremål för maktanspråk från och gränsdragningskonflikter mellan statliga och kommunala intressen.

\section{Yrkesgrupperoch professioner}

Betraktar man FoU-frågan utifrån domänen yrkesgrupper och professioner är det av intresse att studera hur forskningen och användarna förhåller sig till frågan om vad som skall betraktas som innehav och produktion av legitima och giltiga kunskaper. Den diskursiva dimensionen innefattar här de skilda logiska system och sätt att argumentera som professioner eller yrkesgrupper använder. Avgörande för samarbete inom denna dimension är huruvida verksamma inom lokala eller regionala FoU-enheter har sin grund i teorier som överensstämmer med de som är gällande inom forskningen alternativt den politiskt -administrativa sfären. Avgörande är också vilken grad av erkännande som de kunskaper som produceras får inom de båda sfärerna. Inom denna dimension är en grogrund för konflikter mellan forskningen och användarna till exempel synen på de metoder som används för att vinna kunskaper. En konkret konfliktkälla är till exempel i vilken grad sådana metoder som till exempel deltagarorienterad forskning, som av vissa anses vara lämpliga instrument för verksamhetsutveckling inom kommunala verksamheter, betraktas som vetenskapliga eller inte. Som redan nämnts finns det krafter inom bland annat Socialstyrelsen som verkar för att stärka den deltagarorienterade forskningen. Andra aktörer inom forskningen är däremot mer reserverade beträffande dessa metoders vetenskaplighet (se Lysgaard, 1982; Eliasson, 1987; Kalleberg, 1993; Gustavsen, 1996; Mattsson, 2001). En annan potentiell konfliktkälla 
inom denna dimension är frågan om i vilken grad resultaten från den forskning som bedrivs skall, bör eller kan vara direkt användbara i det konkreta sociala arbetet. Många undersökningar visar (som framgår av den forskning som refereras i artikelns inledning) att socialarbetare tillskriver resultat från forskningen relativt liten betydelse för deras praktiska arbete (Tydén, Josefsson \& Messing, 2000), och att de inte sällan ställer sig frågande till den relevans som forskningsmetoder har för deras arbete (Qureshi, 1998:142-143). De nämnda skillnaderna mellan forskare och praktiker kan naturligtvis skapa en situation inom de lokala FoU-enheterna som innebär att de verksamma hamnar i en delikat balansgång mellan de krav som olika aktörer ställer (jfr Ekermo, 2002).

Med utgångspunkt i den sociologiska dimensionen kan frågan om kontroverser kring forskningsanvändning inom domänen yrkesgrupper och professioner beskrivas som frågan om hur långt aktörerna (yrkesgrupperna eller professionerna) skall kunna utvidga sina gränser. Inom denna dimension yttrar sig gränstvister som konkurrens om tjänster, forskningsmedel med mera mellan aktörer från de båda domänerna. Här handlar mötet mellan forskning och praktik bland annat om vilken kompetens som skall anses ha högst meritvärde när det gäller tillsättning av tjänster, samt om de regionala FoU-enheterna kan konkurrera med mer etablerade institutioner när det gäller forskningsanslag. Inom den sociologiska dimensionen är en viktig fråga när det gäller samverkan mellan forskning och praktik också vilka aktörer eller grupper av aktörer (inom forskningen alternativt den politiskt - administrativa sfären) som FoUenheterna kan etablera varaktigt samarbete med, och därmed också få legitimitet för sin verksamhet av. Sådana förhållanden som hur olika professioner (forskare vid universitet respektive FoU-ansvariga i den kommunala organisationen) förstår sin identitet och sin professions och organisations huvudsakliga arbetsuppgifter och huruvida sådana uppfattningar sammanfaller med varandra är viktiga frågor i detta sammanhang.

Utifrån den psykologiska dimensionen slutligen, kan frågan om potentiella konflikter inom domänen yrkesgrupper och professioner förstås som de olika »investeringar» och intressen, i till exempel utbildning, personliga åtaganden med mera, som enskilda aktörer gör i frågor som rör forskningen och dess användning, och därför har anledning att "försvara». Här framstår det som uppenbart att de ansträngningar, när det gäller att förkovra sig i till exempel ett deltagarorienterat forskningsperspektiv eller någon annan forskningsinriktning, som enskilda individer på strategiska positioner inom den aktuella domänen gör, naturligtvis påverkar deras villighet att ge stöd till eller delta i samarbete som har andra utgångspunkter (jfr Brante, 1984, 1988). Enskilda aktörers världsbilder och tolkningsramar har därför betydelse för hur mötet mellan forskning och praktik faktiskt gestaltar sig.

\section{Organisationer och organisatoriska nätverk}

Inom domänen organisationer och organisatoriska nätverk är det relevant att studera 
mötet mellan forskningen och dess användare med utgångspunkt i förhållanden av administrativ karaktär, till exempel hur verksamheter finansieras och hur formella beslutshierarkier är uppbyggda.

Inom den diskursiva dimensionen rör frågan de ideologiska skillnaderna i de organisationer som de inblandade aktörerna i FoU-verksamheter är knutna till. I detta sammanhang kan sägas att synen på den kommunala organisationens funktion och innehåll under det senaste decenniet varit utsatt för mycket större förändringar än den statliga förvaltningen (inom vilken bl.a. universitet och högskolor återfinns).

Högskolorna och universiteten har under 1990-talet haft en bibehållen anslagsnivå. Den kommunala verksamheten har dock kraftigt omvärderats. Denna förändring har skett under inflytande av stagnerande ekonomiska resurser, men också som en följd av diversifiering i betydelsen tillförande av fler och fler uppgifter (jfr Lindqvist, 1998). De förändrade villkoren har medfört att kommunerna varit mottagliga för en ny syn på ekonomi, management och kvalitetsstyrning (jfr. Svenska kommunförbundet, 1996; Bejerot \& Hasselbladh, 2002). Den förändrade synen inom kommunerna på denna typ av frågor har också ett klart samband med de anspråk som från kommunalt håll görs på FoU-enheterna som verktyg för verksamhets- och kunskapsutveckling. Ekermo (2002:144) finner till exempel att det mest framträdande temat $i$ argument för tillskapandet av kommunala lokala FoUenheter med anknytning till socialtjänsten var resursknapphetsargumentet. Med detta avses en strävan att söka använda befintliga skattemedel på ett effektivare sätt. Man kan anta att denna typ av krav från kommunalt håll har haft betydelse för hur mötet mellan den universitets- och högskoleförlagda forskningen och den kommunala praktiken gestaltar sig. I Ekermos studie framgår också att det finns en utbredd kritik mot den akademiska forskningen för att den "inte har lyckats tillgodose den stora efterfrågan på praktisk tillämpad forskning“ (s 145). Ekonomi-, styrnings- och resursanvändningsfrågor nämns dock inte specifikt i detta sammanhang, men det kan ändå antas att de spelar en viktig roll.

Inom den sociologiska dimensionen med anknytning till domänen organisationer och organisatoriska nätverk handlar frågan om mötet mellan forskning och praktik bland annat om i vilken mån de administrativa ramarna för FoU -miljöer så att säga »tillåter« att ett närmande sker till användarnas kontext och vice versa. Potentiella hinder för ett närmande mellan forskning och praktik är till exempel skillnader i anställningsformer, löner med mera, men också i vilken mån forskningen respektive den kommunala världen har en flexibilitet som tillåter att olika typer av arbetsuppgifter varvas eller att anställda samarbetar över institutionsgränserna. Det finns förhållanden som tyder på att anställda inom lokala FoU-enheter med anknytning till socialtjänsten upplever problem på detta område och därför söker hålla verksamheterna i möjligaste mån "frikopplade» från såväl universitetsvärlden som den kommunala hierarkin (jfr Ekermo, 2002: 164-172).

\section{Modellens användbarhet}

Diskussionen kring den analytiska model- 
len (figur 1) har på grund av utrymmesmässiga skäl varit skissartad. Trots detta bör det ha framgått att modellen har ett värde för att förstå mötet mellan forskningen och dess användare. Modellen belyser forskningsanvändningsfrågan utifrån ett relations- och samverkansperspektiv snarare än utifrån ett överföringsperspektiv. I takt med att sociala determinanter för forskning och forskningsanvändning kommit att få ökad uppmärksamhet i teoribildning är detta en fördel (jfr Brante, 1984, 1988, 1990; Gibbons mfl., 1994). En annan fördel är att modellen bidrar till att systematisera relationsfrågan på ett tydligt och med utgångspunkt från vedertagen samhällsvetenskaplig teori logiskt sätt. Trots modellens generella karaktär utgör den dessutom ett raster utifrån vilket analyser kan göras som tar hänsyn till specifika kontextuella förhållanden. I dessa analyser kan fler betydelsefulla aktörer och intressenter än enbart forskare och användare synliggöras och problematiseras. Modellen öppnar med andra ord upp för att skärskåda den grundläggande struktur inom vilken samspelet mellan forskning och användning sker. Den bör därför kunna vara användbar i en analys av varför det finns eller varför det inte finns en intensiv och varaktig samverkan mellan forskare och användare. På detta sätt kompletterar modellen tidigare teorier om forskningsanvändning som har samspelet mellan forskare och användare som huvudfokus. Detta eftersom dessa modeller haft en relativt svag koppling till den sociala kontexten (jfr Cheol, 1997; Rich, 1997).

En avsevärd nackdel med att använda modellen på det sätt som gjorts i artikeln är att det med utgångspunkt i de nio fält som modellen innehåller ännu så länge finns ett bristande empiriskt underlag för att analysera mötet mellan forskning och praktik. Speciellt gäller denna invändning det som i modellen omnämns den psykologiska dimensionen. I takt med att FoU-frågan förmodligen får ett ökat intresse inom forskning i socialt arbete kommer denna brist emellertid att kunna åtgärdas. ${ }^{10}$

10 I samband med färdigställandet av föreliggande artikel utkom en av Socialstyrelsen finansierad utvärdering av FoU-miljöer inriktade mot individ- och familjeomsorgen (Socialstyrelsen, 2002a). På grund av att slutförandet av artikeln i tid sammanföll med publiceringen av den nämnda utvärdering har emellertid resultaten från den inte kunnat integreras $i$ analysen.

\section{Referenser}

Albæk, Erik (1988) Fram sandhet till information. evalueringsforskning i USA - før og nu. København: Akademisk Forlag.

Ashford, Jose. B \& LeCroy, Craig. W (1991) Problem solving in social work practice: Implications for knowledge utilization. Research on social work Practice, 1: 3, 306-319.
Baklien, Bergljot (1983) The use of social science in a Norwegian ministry: As a tool of policy or mode of thinking, Acta Sociologica, 26: 1, 33-47.

Bejerot, Eva \& Hasselbladh, Hasse (2002) Kvalitet utan gränser. Lund: Academia Adacta.

Bergmark, Åke (1993) Om utvärdering av sociala 
metoder. Socionomen, forskningsupplement, 1, 24-34.

Bergmark, Åke \& Lundström, Tommy (2000) Kunskap och kunskapssyn: om socialarbetare inom socialtjänsten, Socionomen, Forskningssupplement, nr 12, 1-16.

Bergström, Eva (1991) Har forskning och försök förändrat socialkontoren i Sverige? Nordiskt socialt arbete, 11:4, 3-12.

Brante, Thomas (1984) Vetenskapens sociala grunder - en studie av konflikter i forskarsamhället. Stockholm: Rabén \& Sjögren.

Brante, Thomas (1988) Kontroversstudier - förslag till ett forskningsprogram, Vest: Tidskrift för vetenskapsstudier, 3: 5-6, 59-67.

Brante, Thomas (1990) Kontroversstudier - ett forskningsprogram, del 2. Tidskrift för vetenskapsstudier, 5: 4, 3-17.

Brante, Thomas (1995) Kunskapsformer och samhällsinstitutioner. Projektansökan till Humanistisk-samhällsvetenskapliga forskningsrådet (opublicerat manuskript).

Brulin, Göran (1998) Den tredje uppgiften. Högskolan och omgivningen i samverkan. Stockholm: SNS förlag.

Caplan, Nathan (1979) The two communities theory and knowledge utilization. American Behavioural Scientist, 22: 3, 459-470.

Cheetham, Juliet (1998) Disciplinary research agendas and institutional arrangements for evaluation research. Scandinavian Journal of Social Welfare, 7:2, 159-166.

Cheol, H. (1997) Issues for the new thinking of knowledge utilization: introductory remark. Knowledge and Policy, 10: 3, 3-11.

Danermark, Berth, Ekström, Mats, Jakobsen, Liselott \& Karlsson, Jan C. (1997) Att förklara samhället. Lund: Studentlitteratur.

Danermark, Berth \& Kullberg, Christian (1999) Samverkan: Välfärdsstatens nya arbetsform. Lund: Studentlitteratur.

DeMartini J. R. \& Whitbeck, L. B. (1986) Knowledge use as knowledge creation. Knowledge; Creation, Diffusion, Utilization, 7: 4, 383-396.

Eikeland, Olav \& Finsrud, Henrik, D., red, (1995) Research in action/ Forskning og handling.
Søkelys på aksjonsforskning. Oslo: Arbeidsforskningsinstituttet.

Ekermo, Mats (2002) Den mångtydiga FoU-idén - lokala FOU-enheters mening och betydelse. Örebro universitet: Institutionen för socialt arbete (Örebro studies in social work 2).

Eliasson, Rosmari (1987) Forskningspraktik och perspektivval. Lund: Studentlitteratur.

Eliasson Lappalainen, Rosmari \& Szebehely, Marta (1996) „Äldreomsorg, kvalitetssäkring och välfärdspolitik« I Palme, J. \& Wennemo, I., red,: Generell välfärd. Hot eller möjlighet? Stockholm: Socialdepartementet. Välfärdsprojektet. Skriftserien. Fakta/kunskap nr 3.

Engelstad, Per, H. (1993) „Dialogkonferensen - en metod för forskningsstödd verksamhetsutveckling« I Holmer, J. \& Starrin, B., red,: Deltagarorienterad forskning. Lund: Studentlitteratur.

Eriksson, J. (1986) „Byggforskningens samhällsrelevans" I Solbe. B., red,:. Vishetens frukter. Gävle: Statens institut för byggforskning. (Refererad i Nydén, M., 1992. FoU utvärdering och användning. En studie av utvärdering av forskning och utvecklingsarbete, dess organisation och användning. Stockholm: Byggforskningsrådets vetenskapliga nämnd. BVN Skriftserie 1992:1).

Gibbons, M., Limoges, C., Nowotny, H., Schwartzman, S., Scott, P. \& Trow, M. (1994) The new production of knowledge. The dynamics of science and research in contemporary society. London: Sage.

Gieryn, Thomas (1983) Boundary work and the demarcation of science from non-science: Strains and interest in professional ideologies of scientists. American sociological review, 48, 781-795.

Ginsberg, Mark, B. \& Gorostiago, Jorge. M (2001) Relationship between theorist/researcher and policy makers/practitioners: Rethinking the two-cultures thesis and the possibility of dialogue, Comparative education review, 45: 2, 173-197.

Gustavsen, Bjørn (1990) Vägen till bättre arbetsliv. strategier och arbetsformer $i$ ett utvecklingsarbete. Stockholm: Arbetslivscentrum.

Gustavsen, Bjørn (1996) Development and the 
social sciences. An uneasy relationship. I Toulmin, Stephen \& Gustavsen, Bjørn, red,: Beyond theory: changing organizations through participation. Philadelphia, Penn.; Amsterdam: John Benjamins Publ.

Gustavsen, Bjørn \& Sørensen, Bjørg, Aase (1995) Aksjonsforskning. I Eikeland, O. \& Finsrud, Henrik, D., red,: Research in action/ Forskning og handling. Søkelys på aksjonsforskning. Oslo: Arbeidsforskningsinstituttet.

Halleröd, Björn (1991) Den svenska fattigdomen. En studie av fattigdom och socialbidragstagande. Lund: Arkiv.

Holstein, James. A \& Miller, Gale (1993) Reconsidering Social Constructionism. I Holstein, J. A. \& Miller, G., eds,: Reconsidering Social Constructionism. Debates in Social Problems Theory. Hawthorne, NY: Aldine de Gruyter.

Johansson, Roine (2002) Nyinstitutionalismen inom organisationsanalysen. Lund: Studentlitteratur.

Kalleberg, Ragnvald (1993) "Konstruktiv samhällsvetenskap« I Holmer, J. \& Starrin, B., red,: Deltagarorienterad forskning. Lund: Studentlitteratur.

Kennedy, M. M. (1983) Working knowledge. Knowledge: Creation Diffusion, Utilization, 4: 5, 193-21.

Kouzes, J. M. \& Mico, P. S. (1979) Domain theory: An introduction to Organizational Behaviour in Human Service Organizations. The Journal of Behavioral Science, 15, 4, 449-469

Lagerkrantz, Karen (1998) Skilda världar - Om mötet mellan socialt vardagsarbete och forskningen. FoU Skåne. Skriftserie. 1998:1.

Landry, Réjean, Amara, Nabil \& Lamiri, Moktar (2001) Utilization of social science knowledge in Canada. Research Policy, 30:2, 333-349.

Larsen, Judith (1980) Knowledge utilization, Knowledge, 1:3, 421-442. (refererad i Nilsson, K. \& Sunesson, S. (1988) Konflikt, kontroll, expertis. Att använda social forskning. Lund: Arkiv Förlag).

Lindqvist, Rafael (1998) Organisation och välfärdsstat. Lund: Studentlitteratur.

Lindsey, Duncan \& Kirk, Stuart, A. (1992) The role of social work journals in the development of a knowledge base for the profession, Social Service Review, 66: 2, 295-310.

Lundmark, Lars-Erik (1997) Kunskapssyn och kunskapsbildning. I Tydén, T., red,: Partnerskap för kunskapsutveckling. Forskning och samhälle. Stockholm: HLS Förlag.

Lysgaard, Sverre (1982) Utviklingsoppgaver i sosiologien. faget som vitenskap og profesjon. Sociologisk forskning, 19:1-2, 61-79.

Marsh, Jeanne. C. (2002) Using knowledge about knowledge utilization, Social work, 47: 2, 101104.

Martin, B. R. \& Etzkowitz, H. (2000) The origin and evolution of the university species. VEST, 15: 3-4, 9-34.

Mattsson, Matts (2001) Stenar under vattenytan - forsknings- och utvecklingsarbete problematiserat. Lund: Studentlitteratur.

Molander, Bengt (1996) Kunskap i handling. Göteborg : Daidalos.

Molander, Bengt (1997) Arbetets kunskapsteori. Stockholm: Dialoger.

Morén, Stefan (1992) Förändringens gestalt. Om villkoren för mänskligt bistånd. Stockholm: Publica.

Mullen, E. J. (1998) Linking the university and the social agency in collaborative evaluation research: principles and examples. Scandinavian Journal of Social Welfare, 7:2, 152-158.

Naustdalslid, Jon (1990) „Organisatoriske villkor for bruk av samfunnsforskning". I Tydén, T., red,: Kunskapsöverföring och kunskapsvård. Falun: Dalarnas forskningsråd och forum för kunskapsvård. DFR-rapport 1990:4.

Nilsson, Kjell \& Sunesson, Sune (1988) Konflikt, kontroll, expertis. Att använda social forskning. Lund: Arkiv Förlag.

Nitsch, Ulrich (1990) »Det räcker inte med fakta om forskningsinformation till bönder" I Tydén, T., red,: Kunskapsöverföring och kunskapsvård. Falun: Dalarnas forskningsråd och forum för kunskapsvård. DFR-rapport 1990:4.

Nydén, Michael (1992) FoU utvärdering och användning. En studie av utvärdering av forskning och utvecklingsarbete, dess organisation

Christian Kullberg: Hinder och möjligheter för forskningsresultats användning - förslag till ... 
och användning. Stockholm: Byggforskningsrådets vetenskapliga nämnd. BVN Skriftserie 1992:1.

Paisley, William (1993) Knowledge utilization: the role of new communication technologies. Journal of the American Society for Information Science, 44: 4, 222-234.

Qureshi, Hazel (1998) Internal and external evaluation in social work. Scandinavian journal of social welfare, 7:2, 137-144.

Rich, Robert. F (1997) Mesuring knowledge utilization: Processes and outcomes. Knowledge and Policy, 10: 3, 11-23.

Riecken, Henry, W (1969) Social sciences and social problems, Social Science Information, 8: 1, 102-129.

Roos, Hans-Edvard (1996) Tre decennier aktionsforskning. I Sahlin, I., red,: Projektets paradoxer. Lund: Studentlitteratur.

Roos, Hans-Edvard (1998) Participatorisk forskning i kunskapssamhället. I Eikeland, Olav \& Fossestøl, Knut, red.: Kunnskapsproduksjon $i$ endring. Oslo Arbeidsforskningsinstituttets skriftserie nr 4.

Salonen, Tapio (1994) Margins of Welfare. Stockholm: Fritzes.

Salonen, Tapio (1996) Övervältringar inom socialsektorn - effekter av statliga nedskärningar $p a ̊$ socialbidragshushåll. Stockholm: Svenska kommunförbundet.

Saltman, Joan, E. E. \& Greene, Roberta (1993) Social workers' perceived knowledge and use of human behavior theory. Journal of Social Work Education, 29: 1, 88-99.

Schön, Donald, A. (1983) The reflective practitioner: how professionals think in action. New York: Basic Books.

Socialstyrelsen (1997a) Om praktikrelaterade forskningsmiljöer. Gränsen som mötesplats. Socialstyrelsen. Utveckling. Erfarenheter från lokala projekt.

Socialstyrelsen (1997b) Om programområdet Forskning-Praktik. Planeringsunderlag 970327, Socialtjänstgruppen, Utvecklingsenheten (Refererad i Ekermo, 2002).

Socialstyrelsen (1998) Två världar - skilda per- spektiv? Kunskapscentra inom kommunernas socialtjänst. Socialstyrelsen (SoS-rapport 1998:2).

Socialstyrelsen (2000) Nationellt stöd för kunskapsutveckling $i$ socialtjänsten. Stockholm: Socialstyrelsen (SoS- rapport 2000: 12).

Socialstyrelsen (2002a) Utvärdering av FoU - en studie av FoU-enheter inriktade på individ- och familjeomsorg. Stockholm: Socialstyrelsen.

Socialstyrelsen (2002b) Forskning och praktik (4.11.2002). http://www.sos.se/sos/omsos/ enheter/cus.htm

Soydan, Haluk. (1998) Evaluation research and social work. Scandinavian Journal of Social Welfare, 7:2, 74-78.

Spector, Malcolm \& Kitsuse, John, I. (1977) Constructing Social Problems. Menlo Park, CA: Cummings Publishing Company.

Starrin, Bengt (1993) »Tillämpad social forskning" I Holmer, J. \& Starrin, B., red,: Deltagarorienterad forskning. Lund: Studentlitteratur.

Stål, Rolf \& Svedberg, Lars (1987) Några centrala frågeställningar. I Stål, R. \& Svedberg, L., red,: Det ovissa mötet - om fält och forskning i socialt arbete. Stockholm: Rabén \& Sjögren.

Sunesson, Sune (1974) Politik och organisation. Staten och arbetarklassens organisationer. Lund: Arkiv Förlag.

Sunesson, Sune (1981) Byråkrati och historia. Fem studier i politik och organisation. Lund: Arkiv Förlag.

Sunesson, Sune (1989) Evaluering av center for social utvikling-elsket men forladt. København: Center for sosial utvikling. (Refererade i Hansson, J-H. (1993) Organizing normality. Essays on organizing day activities for people with evere mental disturbance. Linköpings universitet: Tema Hälso- och sjukvården i samhället. Linköping Studies in Art and Science 88.

Svenska kommunförbundet (1996) En lärande organisation: kvalitetsutveckling inom skola och socialtjänst. Stockholm : Kommentus.

Tengvald, Karin (1995) Behov av resultatorienterad kunskapsutveckling i socialt arbete. I Bilaga 7 till SOU 1995:58 Kunskap och kompetensutveckling inom socialtjänsten. Delbetänkande 
från socialtjänstkommittén. Stockholm: Socialdepartementet.

Tengvald, Karin (1997a) Perspektiv på kvalitetssäkring- uppföljning, utvärdering och dokumentation av socialt arbete, Nordisk sosialt arbeid, 17: 1, 20-29.

Tengvald, Karin (1997b) Utvärdering av socialt arbete. Social forskning, 12: 2, 9-11.

Thyer, Bruce, A. (2001) What is the role of theory in research on social work practice? Journal of Social Work Education, 37: 1, 9-25).

Tydén, Thomas (1993) Knowledge interplay. User-oriented Research Dissemination trough synthesis Pedagogics. Uppsala: Uppsala Studies in Education 50.

Tydén, Thomas (1995) Kommunerna möter forskningen. En litteraturgenomgaing och probleminventering. Dalarnas forskningsråd . DFR-rapport 1995:1.

Tydén, Thomas (1997a) »Nya drivkrafter till samverkan mellan vetenskap och praktik» I Tydén, T., red;: Partnerskap för kunskapsutveckling. Forskning och samhälle. Stockholm: HLS Förlag.

Tydén, Thomas (1997b) „Forskare - praktiker: Nya förutsättningar för det goda mötet« I Tydén, T. Den reflekterande kommunen. Kommuner och forskning i samverkan. Stockholm: HLS Förlag.

Tydén, Thomas (1997c) "Ett forskningsprogram om samspelet mellan vetenskap och praktik" I Tydén, T., red,: Partnerskap för kunskapsutveckling. Forskning och samhälle. Stockholm: HLS Förlag.

Tydén, T., Josefsson, C. \& Messing, J. (2000) Socialsekreterare och kunskapsbildning. Stockholm: Socialstyrelsen.

Utbildningsdepartementet (1999) Att finansiera forskning och utveckling. Rapport frän arbetsgruppen för fortsatt beredning av myndighetsstruktur för forskningsfinansiering (Ds 1999: 68). Stockholm: Fakta Info direkt. (Refererad i Ekermo, 2002).

Weiss, Carol, H red. (1977) Using Social Research in Public Policy Making. Massachusetts: Lexington Books.

Weiss, Carol, H \& Bucuvalas, Michael, J (1977). The challenge of social research to decision making. I Weiss, Carol, H red. Using Social Research in Public Policy Making. Massachusetts: Lexington Books

Westlund, Peter (1997) Praktikens FoU - socialtjänst $i$ utveckling. Karlshamn: Nätverksprojektet.

\section{Summary}

\section{Obstacles and possibilities in the utilization of research - a proposal for an analytical model}

Studies of research utilization indicate that the relation between research and users is a central factor in the understanding of the conditions under which research is used. On the basis of such findings, a theoretical model is introduced, which describes research utilization or the lack of such uti- lization as obstacles and possibilities with co-operation and collaboration embedded in the relation between research and its users. The model is applied in a discussion of potential controversies in social work research and development. 